\title{
Non-Malformative Emergency Abdominal Surgery in Children Aged 0 - 5 Years
}

\author{
Lassey James Didier ${ }^{*}$, Harissou Adamou², Oumarou Habou², Ousseini Adakal ${ }^{3}$, Kadi Ide1, \\ Younssa Hama1, Ibrahim Amadou Magagi ${ }^{2}$, Moussa Gagara ${ }^{3}$, Maman Bachir Abdoulaye4, \\ Rachid Sani ${ }^{1}$
}

\footnotetext{
${ }^{1}$ Department of Surgery and Surgical Specialties, National Hospital of Niamey, Faculty of Health Sciences of the UAM, Niamey, Niger ${ }^{2}$ Department of Surgery and Surgical Specialties, Zinder National Hospital, Faculty of Health Sciences of the University of Zinder, Zinder, Niger

${ }^{3}$ Department of Anesthesia, Resuscitation and Emergencies, Niamey National Hospital, Niamey, Niger

${ }^{4}$ Department of Surgery and Surgical Specialties, Faculty of Health Sciences of the University of Maradi, Niamey, Niger Email: *jamesdidier3@gmail.com
}

How to cite this paper: Didier, L.J., Adamou, H., Habou, O., Adakal, O., Ide, K., Hama, Y., Magagi, I.A., Gagara, M., Abdoulaye, M.B. and Sani, R. (2021) Non-Malformative Emergency Abdominal Surgery in Children Aged 0 - 5 Years. Surgical Science, 12, 211-217.

https://doi.org/10.4236/ss.2021.127023

Received: June 17, 2021

Accepted: July 23, 2021

Published: July 26, 2021

Copyright $\odot 2021$ by author(s) and Scientific Research Publishing Inc. This work is licensed under the Creative Commons Attribution International License (CC BY 4.0).

http://creativecommons.org/licenses/by/4.0/

\begin{abstract}
Childhood abdominal surgery emergencies are a major challenge and problematic for the surgeon. The objective is to assess the pattern of non-malformative emergency abdominal surgery in children under 5 years old and to evaluate their management. Patients and Methods: A retrospective study of children under five years of age operated between January 2015 and December 2019 who presented with non-malformative abdominal surgical emergency at the Niamey National Hospital. Results: We collected 327 patients aged 0 to 5 years who underwent surgery for abdominal emergency. The average age was $2.8 \pm$ 0.7 years. Boys accounted for $70.64 \%(n=231)$ of the cases. Non-traumatic emergencies accounted for $97 \%(\mathrm{n}=317)$ of the cases. They were dominated by peritonitis in $44.6 \%(n=146)$ and strangulated hernia in $43.7 \%(n=143)$. Peritonitis was attributed to ileal typhoid perforation in $85.61 \%(\mathrm{n}=125)$ cases. The strangulated hernias were umbilical at $87.41 \%(\mathrm{n}=125)$ and inguinal at $12.59 \%$ $(\mathrm{n}=18)$. Abdominal trauma accounted for $3 \%(\mathrm{n}=10)$; including 6 cases of abdominal contusion and 4 cases of penetrating wound. Intestinal resection with or without stoma was performed in $28.44 \%(\mathrm{n}=93$ ). Postoperative complications were observed in $8.5 \%(n=28)$ of the cases and mortality was $5.5 \%$ $(\mathrm{n}=18)$. Conclusion: Non-malformative emergency abdominal surgery for children under 5 years was dominated by peritonitis. The morbidity and mortality are high. Fight against disease due to dirty hands and fecal peril like such as typhoid fever will reduce their frequency, but also improve the prognosis.
\end{abstract}

\section{Keywords}

Surgical Abdominal Emergencies-Peritonitis, Child, Prognosis, Niger 


\section{Introduction}

Childhood abdominal emergency surgery is a major challenge and a significant burden for the surgeon wide world [1]-[6]. These difficulties are inherent technical difficulties, on the one hand, and consultation delays on the other, due to several factors that characterize countries with limited resources [3] [4] [5] [6]. In particular, most of the children come from rural areas and that the parents have tried a traditional treatment or auto-medication based on street drugs [2] [3]. Many abdominal surgical conditions affect these children [4]. In low-income countries, the prognosis for surgical emergencies is poor [2]-[7]. In fact, this seriousness is linked to the delay in diagnosis resulting from a late consultation, the poor condition of patients on admission, poor preparation of patients. However, management has benefited greatly from technical progress in developed countries; the speed and quality of surgical diagnosis, the quality of preoperative resuscitation, and improved anesthetic care have improved the prognosis [5]. The aim of this study was to assess the pattern of non-malformative emergency abdominal surgery of children under 5 years old and to evaluate their management.

\section{Patients and Methods}

This was a retrospective and descriptive study carried out at the Niamey National Hospital over 5 years, from January 1, 2015, to December 31, 2019. All children aged 0 to 5 were included in the study. For non-malformative abdominal surgical emergency, children whose records cannot be used and those who have malformative affections have been excluded. Frequency, age, sex, indications for surgery, etiologies, surgical procedures performed, morbidity and mortality were variables studied. All patients underwent laparotomy under general anesthesia.

\section{Results}

During period study, non-malformative emergency abdominal surgery in children aged 0 to 5 years was accounted for 4.17\% (327/7842) of all surgical emergencies. These were 231 boys and 96 girls, i.e. a sex ratio of 2.41 . The mean age was $2.8 \pm 0.7$ years (range: 2 months and 5 years). Patients less than one year old accounted for $18.65 \%(n=61)$ and $53.21 \%(n=174)$ were between 3 and 5 years old. The average consultation time was 2.1 days (range: 1 hour and 14 days). Functional signs of admission were dominated by abdominal pain in $44.03 \%$ (n $=144)$, associated or not with transit disorders at $26.29 \%(\mathrm{n}=86)$, vomiting in 24.77\% $(\mathrm{n}=81)$ and fever in $9.78 \%(\mathrm{n}=32)$. Physical examination found abdominal distension in $39.44 \%(\mathrm{n}=129)$, strangulated umbilication hernia in $38.22 \%(\mathrm{n}=125)$ and at $5.50 \%(\mathrm{n}=18)$ it was a strangulated inguinal hernia. On digital rectal examination, Douglas's pouch was painful in $28 \%$ of cases, and an intussusception was noticeable in $1.4 \%$ of cases $(n=5)$. Abdominal X-ray was performed in 56 patients $(17.12 \%)$ and revealed pneumoperitoneum in 45 cases (80.36\%), hydro-aeric levels and diffuse grayness were found in $7.14 \%$ of cases 
each. Abdominal ultrasound, performed in 21 cases, revealed a rosette image in 13 cases $(61.90 \%)$. Acute generalized peritonitis and strangulated hernia were the main indications for surgery [Table 1].

Ileal perforations, presumed to be of typhoid origin, represented $38.22 \%$ ( $\mathrm{n}=$ 125) of the lesions observed. Bowel resections with or without the restoration of digestive continuity were performed in $29.35 \%(n=96)$. The different actions performed depending on the lesions have been reported in Table 2.

The immediate postoperative effects were simple in $85.9 \%$ of cases $(n=281)$. The morbidity rate was $8.5 \%(\mathrm{n}=28)$ and 18 patients had died $(5.5 \%)$. Wall suppuration was the main complication with $5.8 \%(\mathrm{n}=19)$ and peritonitis was the main contributor to complications [Table 3].

Table 1. Distribution of patients according to surgical indications.

\begin{tabular}{|c|c|c|c|}
\hline \multicolumn{2}{|c|}{ Surgical indications } & \multirow{2}{*}{$\begin{array}{c}\text { Number } \\
145\end{array}$} & \multirow{2}{*}{$\begin{array}{c}\text { Percentage (\%) } \\
44.34\end{array}$} \\
\hline \multirow{8}{*}{$\begin{array}{l}\text { Non-traumatic } \\
\text { emergencies }\end{array}$} & Acute peritonitis & & \\
\hline & Strangulated hernia & & \\
\hline & Umbilical $(\mathrm{n}=125)$ & 143 & 43.73 \\
\hline & Inguinal $(\mathrm{n}=18)$ & & \\
\hline & Acute intussusception & 22 & 6.73 \\
\hline & Acute appendicitis & 2 & 0.61 \\
\hline & Bowel obstruction & 4 & 1.21 \\
\hline & Liver abscess & 1 & 0.3 \\
\hline \multirow{2}{*}{$\begin{array}{c}\text { Traumatic } \\
\text { emergencies }\end{array}$} & Abdominal contusion & 6 & 1.84 \\
\hline & Penetrating abdominal wound & 4 & 1.23 \\
\hline Total & & 327 & 100 \\
\hline
\end{tabular}

Table 2. Distribution of patients according to perioperative view and procedures.

\begin{tabular}{|c|c|c|c|}
\hline $\begin{array}{c}\text { Surgical } \\
\text { indications }\end{array}$ & Perioperative findings & Surgical procedures & Number (\%) \\
\hline \multirow{5}{*}{ Acute peritonitis } & \multirow{3}{*}{$\begin{array}{c}\text { Ileal perforation } \\
\text { and other perforated } \\
\text { ileal necrosis }\end{array}$} & Ileal excision and suture & $51(15.6 \%)$ \\
\hline & & Ileal resection and ileostomy & $38(11.6 \%)$ \\
\hline & & Ileal resection and anastomosis & $38(11.6 \%)$ \\
\hline & Appendicular & Appendicectomy & $12(3.7 \%)$ \\
\hline & Galbladder perforation & Retrograde cholecystectomy & $1(0.3 \%)$ \\
\hline \multirow{2}{*}{ Strangulated hernia } & Anse viable & Simple herniorrhaphy & $132(40.36 \%)$ \\
\hline & Intestinal necrosis & Intestinal resection and herniorraphy & $11(3.4 \%)$ \\
\hline \multirow{2}{*}{$\begin{array}{c}\text { Acute } \\
\text { intussusception }\end{array}$} & Viable loop & Desinvagination & $16(5 \%)$ \\
\hline & Intestinal necrosis & Rigth hemicolectomy & $6(1.8 \%)$ \\
\hline \multicolumn{2}{|l|}{ Acute appendicitis } & Appendectomy & $2(0.6 \%)$ \\
\hline \multirow{4}{*}{$\begin{array}{c}\text { Intestinal } \\
\text { obstruction }\end{array}$} & \multirow{3}{*}{$\begin{array}{c}\text { Without } \\
\text { intestinal necrosis }\end{array}$} & Adhesiolysis & $5(1.5 \%)$ \\
\hline & & Flange release & $3(0.9 \%)$ \\
\hline & & Devolvulation & $1(0.3 \%)$ \\
\hline & With intestinal necrosis & Colostomy & $3(0.9 \%)$ \\
\hline
\end{tabular}




\section{Continued}

\begin{tabular}{|c|c|c|c|}
\hline Liver abscess & & Drainage & $1(0.3 \%)$ \\
\hline \multirow{3}{*}{$\begin{array}{c}\text { Abdominal } \\
\text { contusion and } \\
\text { Penetrating wound }\end{array}$} & Ruptured spleen & Splenectomy & $2(0.6 \%)$ \\
\hline & Splenic contusion & Packing & $3(0.9 \%)$ \\
\hline & Abdominal wall wounds & Exploration and hemostasis & $4(1.2 \%)$ \\
\hline
\end{tabular}

Table 3. Postoperative complications distribution according to diagnosis.

\begin{tabular}{ccc}
\hline Diagnosis & Postoperative complications & Number (\%) \\
\hline Peritonitis & $\begin{array}{c}\text { Wall suppuration }(\mathrm{n}=15) \\
\text { Postoperative peritonitis }(\mathrm{n}=4)\end{array}$ & $19(5.8)$ \\
Acute intussusception & Wall suppuration $(\mathrm{n}=2)$ & $4(1.2)$ \\
Wall wound & Anemia $(\mathrm{n}=2)$ & $2(0.6)$ \\
Strangulated hernia & Wall suppuration $(\mathrm{n}=2)$ & $3(0.9)$ \\
Total & Anemia $(\mathrm{n}=3)$ & $\mathbf{2 8}(\mathbf{8 . 5})$
\end{tabular}

Among the eighteen deaths, 7 occurred immediately after surgery. Death occurred after peritonitis (13 cases), strangulated hernia with necrosis (3 cases), and intussusception also with necrosis ( 2 cases).

The average length of hospital stay was 10.5 days with extremes ranging from 1 to 90 days. It is between 4 and 6 days in $56.96 \%(n=187)$.

\section{Discussion}

The epidemiological characteristics of abdominal surgical emergencies vary according to the pediatric population studied [5] [7] [8]. In this study, the frequency of abdominal surgical emergencies in children under 5 years compared to total emergency surgical admissions was $4.17 \%$. This frequency is lower than other African authors who have found up to a rate of $10.32 \%$ in children aged 0 to 5 years [5] [6] [7]. This difference would be due to the method of sample selection and the type of study. The male predominance in this study is also reported by other authors who claim that abdominal surgical conditions in children are much more common in males [2] [3] [4] [8]. The mean time to consultation was 2.1 days. This delay varies according to the series [2] [3] [4] [5] [9]. Abdominal pain was the main functional sign. It is in fact, the most common symptom in acute abdomens [1]-[14]. This pain associated with signs of peritoneal irritation or an irreducible arching at a weak point of the abdominal wall is strongly suggestive of an abdominal surgical emergency [5] [6] [10]-[15]. The rectal examination performed found a painful Douglas-pouch in $30.5 \%$ of cases. This examination is reported in several studies even though some authors consider it unnecessary in principle, since it is always painful in children [16].

In the literature, abdominal X-ray remains the first-line imaging test for intestinal obstruction well as for digestive perforations and ultrasound in abdominal 
trauma and acute intussusception [17]. Acute peritonitis was the main operative indication for surgery in this study as reported by many other authors [2] [3] [4] [5] [15] [18]. The main etiology of this peritonitis was non-traumatic ileal perforation presumed to be of typhoid origin [5] [6] [15] [18]. Mabiala-Babela et al. [19] reported less peritonitis in their study. This difference could be related to the increased prevalence of typhoid fever in the sub-Saharan area, but also to the fact that our structure is one of the main reference centers for the management of children's surgical emergencies. Strangulated umbilical hernia is common in African pediatric practice, particularly in the black race [20]. The intussusception represented the third cause of abdominal surgical emergencies in our study with $6.6 \%$ similar to the rates found in other publications [19] Abdominal trauma is of little interest to small children but would rather be more frequent in older children [14] [19] [21].

Surgical procedures were based on intraoperative findings. Herniorrhaphy has been performed in most patients with hernias. This same attitude is reported by other authors [2] [5] [6] [20]. For the peritonitis due to a perforation presumed to be typhoid, simple suture excision was the procedure most used when the perforation is single and when the peritoneal cavity was slightly septic. In the presence of several perforations or strong contamination of the abdominal cavity, an ileostomy was performed as reported by some authors [5] [22] [23]. But attitudes differ according to the authors who favor anastomosis resections rather than resections with temporary ostomies, often with many postoperative complications as corollaries [15].

Postoperative morbidity was dominated by surgical site infection. The mortality rate recorded in our series was close to that of the Congolese series [19]. However, it remains high even if it is lower than those found by other authors [5] [6] [22] [23] and could be attributed, on the one hand, to the delay in diagnosis and taking and, on the other hand, to the insufficiency of qualified personnel at the level of the health pyramid but also the low socioeconomic level of the patients [5] [6] [22] [23] [24] [25]. It is necessary to have anesthesiologists, intensive care, physiotherapy and specialized pediatric nursing care.

\section{Conclusion}

Non-malformative abdominal surgical emergencies in children under 5 years old are common. Their etiologies are multiple with significant morbidity and mortality. Their management requires a specialized center and a multidisciplinary approach in order to provide appropriate care. Efforts must be made in this field in our hospital structures in order to improve the prognosis of abdominal surgical emergencies in children. Thus, the fight against diseases of dirty hands and fecal-oral transmission such as typhoid fever can reduce the frequency of peritonitis, the main cause of surgical emergencies in children in our context.

\section{Conflicts of Interest}

The authors declare no conflicts of interest regarding the publication of this paper. 


\section{References}

[1] Onyemaechi, N.O.C., Urube, S.U. and So, E. (2019) Pattern of Surgical Emergencies in a Nigerian Tertiary Hospital. African Health Sciences, 19, 1768-1777. https://doi.org/10.4314/ahs.v19i1.53

[2] Abantanga, F.A., Nimako, B. and Amoah, M. (2009) The Range of Abdominal Surgical Emergencies in Children Older than 1 Year at the Komfo Anokye Teaching Hospital, Kumasi, Ghana. Annals of African Medicine, 8, 236-242. https://doi.org/10.4103/1596-3519.59578

[3] Dan, V., Hazoumé, F.A., Ayiri, B. and Koumakpai, S. (1991) Prise en charge des urgences du nourrisson et de l'enfant. Aspects actuels et perspectives d'avenir. Médecine d Afrique Noire, 38, 752-759.

[4] Seyi-Olajide, J.O. and Ameh, E.A. (2020) Global Health and Surgical Infection: From Neglect to Emerging Frontier. Surgical Infections, 21, 516-522. https://doi.org/10.1089/sur.2020.006

[5] Habou, O., Adamou, H., Amadou, M.M.I., Magagi, A., Adamou, M., Halidou, M., et al. (2015) Urgences chirurgicales digestives de l'enfant à l'Hôpital National de Zinder (Niger): Aspects épidémiologiques, étiologiques et pronostics à propos de 283 cas. Annales de 1 Université Abdou Moumouni de Niamey, 19, 36-42.

[6] Seyi-Olajide, J.O., Anderson, J., Enivwaene, A.O., Ibrahim, S.H., Farmer, D. and Ameh, E.A. (2020) Catastrophic Healthcare Expenditure from Typhoid Perforation in Children in Nigeria. Surgical Infections, 21, 586-591. https://doi.org/10.1089/sur.2020.134

[7] Keita, M., Diallo, M.S.A., Keita, A.K., Diallo, A.F. and Et Balde, I. (2006) Les urgences chirurgicales néonatales dans le service de chirurgie pédiatrique du $\mathrm{CHU}$ Donka. Le Mali medical, 21, 16-20.

[8] Kouma, K., et al. (1991) Prise en charge des urgences du nourrisson et de l'enfant. Aspects actuel et perspectove d'avenir. Médecine d' Afrique Noire, 11, 752-759.

[9] Rakotoarisson, R., et al. (2010) Mortalité pédiatrique aux urgences chirurgicales au CHU d'antananarivo. Revue Tropicale de Chirurgie, 4, 17-19.

[10] Soumah, S.A., Ba, P.A., Diallo-Owono, F.K. and Toure, C.T. (2011) Les abdomens aigus chirurgicaux en milieu africain: Étude d'une série de 88 cas à l'hôpital Saint Jean de Dieu de Thiès. Bulletin Médical dowendo, 13, 13-16.

[11] Diop, P.S., Ba, P.A., Ka, I., Ndoye, J. and Fall, B. (2011) Prise en charge diagnostique des abdomens aigus non traumatiques au service des urgences de l'hôpital général de Grand-Yoff: À propos de 50 cas. Bulletin Médical do Owendo, 13, 42-46.

[12] Chéron, G., Faesch, S. and Chalouhi, C. (2006) Douleurs abdominales du jeune enfant. Pièges et diagnostics. Archives de Pédiatrie, 13, 814-816. https://doi.org/10.1016/j.arcped.2006.03.123

[13] Saliakellis, E., Borrelli, O. and Thapar, N. (2013) Paediatric GI Emergencies. Best Practice \& Research Clinical Gastroenterology, 27, 799-817. https://doi.org/10.1016/j.bpg.2013.08.013

[14] Harouna, Y., et al. (2001) Deux ans de chirurgie d'urgence à l'hôpital de Niamey: Étude analytique et pronostique. Médecine d Afrique Noire, 48, 49-54.

[15] Kassegne, I., Kanassoua, K., Sewa, E.V., Tchanga1, B., Sambiani, J., Ayite, A.E. and Dosshe, E.D. (2015) Prise en charge des urgences abdominales chirurgicales au centre hospitalier universitaire de Kara (Togo): Étude rétrospective a propos de 594 cas sur une période de dix ans. Médecine et Santé Tropicales, 25, 39-43.

[16] Valleteau de Moulliac, J.P.G. (1979) Douleur abdominale chronique de l'enfant. 
Orientations diagnostics et attitudes pratiques. La Revue du Praticien, 29, 3705-3708.

[17] Aigrain, Y. (1989) Affections Digestives Chirurgicales. Pediatrie Editions Marketing Ellipsses (Paris-France), Universités Francophones, Paris, 142-150.

[18] Kassegne, I., Sewa, E.V., Alassani, F., Kanassoua, K.K., Adabra, K., Tchangai, B., Amavi, A.K. and Attipou, K. (2016) Prise en charge des urgences chirurgicales abdominales au centre hospitalier régional de Dapaong (Togo). Journal Africain d Hépato-Gastroentérologie, 10, 85-88. https://doi.org/10.1007/s12157-015-0649-x

[19] Mabiala-Babela, J.R., Pandzou, N., Koutaba, E., Ganga-Zandzou, S. and Senga, P. (2006) Etude rétrospective des urgences chirurgicales viscérales de l'enfant au CHU de Brazaville. Médécine Tropicale, 66, 172-176.

[20] Harouna, Y., et al. (2001) La hernie ombilicale de l'enfant noir africain: Aspects cliniques et résultats du traitement à propos de 52 cas. Médecine d'Afrique Noire, 6, 265-269.

[21] Sani, R., Ngo Bissemb, N.M., Bade, M.A., Baoua, B.M., Illo, A. and Bazira, L. (2004) Les contusions de l'abdomen. Revue de 360 dossiers à l'Hôpital National de Niamey: Niger. Médecine d’ Afrique Noire, 51, 505-508.

[22] Magagi, I.A., Adamou, H., Habou, O., Magagi, A., Halidou, M. and Ganiou, K. (2017) Urgences chirurgicales digestives en Afrique subsaharienne: Étude prospective d'une série de 622 patients à l'Hôpital national de Zinder, Niger. Bulletin de la Société de Pathologie Exotique, 110, 191-197. https://doi.org/10.1007/s13149-016-0499-9

[23] Adamou, H., Amadou, M.M.I., Habou, O., Adamou, M., Magagi, A., Elh Adakal, O., Mahaman, N. and Sani, R. (2015) Retard diagnostique et implication pronostique en milieu africain. Cas des urgences en chirurgie digestive à l'hôpital national de Zinder, Niger. European Scientific Journal, 11, 251-262.

[24] Wind, P., Malamut, G., Guénod, C., et al. (2004) Stratégie des explorations des douleurs abdominales. Encyclopédie Médico-Chirurgicale, 24-039-C-10, 10 p.

[25] Adamu, A., Maigatari, M., Lawal, K. and Iliyasu, M. (2010) Waiting Time for Emergency Abdominal Surgery in Zaria, Nigeria. African Health Sciences, 10, 46-53. 